\title{
Travelling terms and local innovations: The tsotsitaal of the North West province, South Africa
}

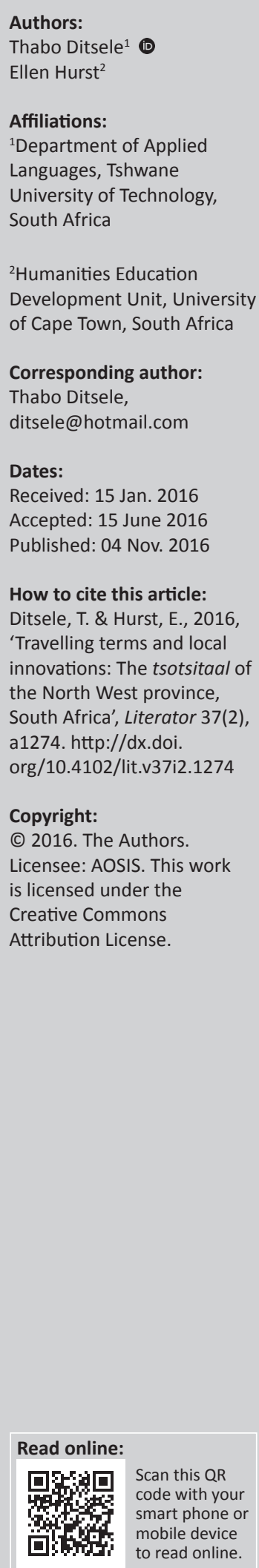

This article focuses on the theme of linguistic innovation and expands on recent studies of the South African linguistic phenomenon tsotsitaal to show that it has travelled from its epicentre of Gauteng province into the North West province (henceforth North West), where it uses Setswana as its Matrix Language because it is the dominant language in the North West. Data were gathered from the North West's three largest cities, namely, Rustenburg, Klerksdorp and Potchefstroom. The article presents examples of tsotsitaal spoken in the three cities and analyses its linguistic structure and lexical items. The significance of this tsotsitaal study is that it is the first to be conducted exclusively amongst first language (L1) Setswana speakers in an environment where the language is the most dominant - the North West. The study confirms previous literature which describes the phenomenon as a register of the urban form. It furthermore suggests that new lexical innovations at a local level are often drawn from the local base language, in this case Setswana, because the local language offers the best opportunities for semantic shift and multiple meanings.

Rondreisende terme en plaaslike vernuwing: Die tsotsitaal van die Noordwesprovinsie, Suid-Afrika. Hierdie artikel fokus op die tema van taalvernuwing en brei onlangse studies van die Suid-Afrikaanse taalverskynsel bekend as tsotsitaal uit, om aan te dui dat dit vanaf sy episentrum in die Gauteng-provinsie oorbeweeg het na die Noordwesprovinsie (voortaan Noordwes), waar Setswana as die Matrikstaal dien omdat dit die dominante taal in Noordwes is. Data is by Noordwes se drie grootste stede, naamlik Rustenburg, Klerksdorp en Potchefstroom, versamel. Die artikel bied voorbeelde van tsotsitaal soos dit in dié drie stede gepraat word en analiseer die taalstruktuur en leksikale items daarvan. Die belang van hierdie studie van tsotsitaal lê in die feit dat dit die eerste van sy soort is wat uitsluitlik onder eerstetaalsprekers (T1) van Setswana uitgevoer is in 'n omgewing (Noordwes) waar dit die heersende taal is. Die studie bevestig vorige navorsing, wat die fenomeen as 'n register van die stedelike vorm beskryf. Dit suggereer voorts dat nuwe leksikale vernuwings op plaaslike vlak dikwels aan die plaaslike basistaal, in hierdie geval Setswana, ontleen word, aangesien die plaaslike taal die beste geleentheid bied vir semantiese verskuiwing en meervoudige betekenisse.

\section{Introduction}

A growing field in sociolinguistics in Southern Africa, and the African continent more broadly, is the investigation into forms of language used by youth, particularly those residing in the multilingual cities of the continent. Examples of these phenomena include Sheng from Kenya, Camfranglais from Cameroon, Nouchi from Ivory Coast and Tsotsitaal from South Africa. Tsotsitaal is known by a number of alternative names, depending on the geographic region, speaker preference and local practice. Some alternative names include flaaitaal, iscamtho, ringas, isiTsotsi and kasitaal (Makalela 2013; Mesthrie \& Hurst 2013; Rudwick 2005). It is known as Setsotsi in the North West province (henceforth North West) because the noun class [se-] in Sotho ${ }^{1}$ languages denotes a language (e.g. Sejapane for Se-Japanese, Sekorea for Se-Korean and Setsotsi for Se-Tsotsi). Tsotsitaal has received great attention in academic literature, and its features, including its linguistic structure, history and functions, have been dealt with in details in other publications (cf. Brookes 2014; Hurst 2009, 2015; Mesthrie 2008; Molamu 2003; Ntshangase 1993).

Tsotsitaal, according to a number of recent authors, should not be described as a language, but instead as a style or register. Mesthrie and Hurst (2013:125) describe it as 'essentially a highly

1.In this context, "Sotho" refers to the following three mutually intelligible languages: Sesotho sa Leboa (also known as Northern Sotho or Sepedi), Setswana (also known as Western Sotho) and Sesotho (also known as Southern Sotho), and not just the latter. 
stylised slang register of an urban form of language, expressing male youth culture within the broader matrix of an urban identity'. ${ }^{2}$ According to Hurst and Mesthrie (2013:5), it first emerged in the mixed townships of Johannesburg, such as Sophiatown, in the 1940s, and subsequently spread to other parts of South Africa. Slabbert and Myers-Scotton (1997:322) state that it functions as the lingua franca of male social interactions, and Hurst (2009:250) notes that these are primarily young black South African males who live in urban townships. Calteaux (1996:59-60) also notes that tsotsitaal is mostly used by men; although women sometimes use it and usually understand what is being said, it is claimed that only certain types of women use it - those of low repute or those who work in 'shebeens'. However, a number of famous South African women during the Sophiatown era, such as Dolly Rathebe, spoke tsotsitaal, and many women today employ tsotsitaal freely in particular contexts and often create their own terms (cf. Maribe \& Brookes 2014).

With regard to the domains of use, Calteaux (1996:60) submits that tsotsitaal is used in informal situations such as 'shebeens' and 'stokvels', in the street, at social gatherings, at soccer matches, in shops, on public transport, etc. Brookes and Lekgoro (2014:149) attest that informal male youth varieties have long been a prominent feature in townships across South Africa, and that they relate to the transitional life stage between childhood and adulthood of young men of African descent, during which time many young men in South Africa's townships participate in peer groups that are part of male youth social networks on the township streets. It should be noted, however, that tsotsitaal is also spoken by older men within peer groups; therefore, whilst 'youth' may innovate tsotsitaal, older people continue to employ it.

Molamu (2003:xxi, xiii) argues that the phenomenon developed for several intertwined reasons: it was born as an expression of creativity and passion, as well as an expression of the sadness, anger and resentment felt by these people dislocated from their sense of identity, and it acted as a bridge amongst young segregated communities that spoke several distinct languages. Ntshangase (1993) remarks that tsotsitaal represents urbanism, slickness, progressiveness, streetwiseness and modernity. Calteaux (1996:61) notes that whilst tsotsitaal may be socially stigmatised as 'bad isiZulu' or 'bad Sesotho', it has covert prestige amongst its speakers; however, tsotsitaal is not used as a language of education or communication in formal domains or institutions.

In terms of its linguistic structure, Hurst and Mesthrie (2013:3) note that tsotsitaal is a linguistic phenomenon common to many South African urban townships, which is constituted primarily by lexical variation with anti-language intentions (cf. Halliday 1975).

2.Tsotsitaal is associated with leisure and pleasure, not the rigours of work. For the latter, the genuine pidgin, Fanakalo (lexified by isizulu) was transported to the early mines and other workspaces of the Witwatersrand from Natal in the 19th century (Mesthrie 1989).
Slabbert and Myers-Scotton (1997) argued the following:

Tsotsitaal is constituted as a code-switching variety, with a nonstandard dialect of Afrikaans as Matrix Language (ML). Afrikaans therefore supplies the morphosyntactic frame of mixed constituents. Into these frames, content elements from other languages (called Embedded Language [EL]) are inserted, as well as some novel words with no known origins. Although there may be a good deal of diversity in the content elements of tsotsitaal (which may come from either the ML or ELs), tsotsitaal is thus very uniform in how it is structured from the morphosyntactic point of view. (Calteaux 1996:57)

However, many authors have challenged the conceptualisation of tsotsitaal as a code-switching variety. As Mesthrie and Hurst (2013:126) argue, the syntactic structure of tsotsitaals is derivative, 'being identical to that of either an existing non-standard variety, or to patterns of syntactic switching already existing in the speech communities'. Furthermore, they suggest that the semantic manipulation and shift that constitute a primary feature of the tsotsitaal lexicon disqualify lexical borrowings from being seen as code-switching. In addition, the evidence that tsotsitaal uses Afrikaans as its base language has been contradicted by many studies showing that, whilst the earliest instantiation of tsotsitaal from Sophiatown did indeed have an Afrikaans syntactic base, tsotsitaal as a register can be inserted into whatever is the available local language (e.g. isiZulu as seen in Rudwick 2005; isiXhosa as seen in Hurst 2008 and Mesthrie \& Hurst 2013; Sesotho sa Leboa as seen in Nkosi 2008 and so on) and that it relies on the most urban form, as explained by Mesthrie and Hurst (2013:125-126):

The real restructuring is at the level of the matrix, urban vernaculars of the wider communities. The base of a tsotsitaal itself is not a standard variety, but always a partially restructured urban one, often having the most deviant syntax on this continuum, that young speakers can come up with.

Research on tsotsitaal suggests that Afrikaans is the first matrix language (ML) of tsotsitaal, and there was a shift to two new MLs, namely, isiZulu and Sesotho in the 1950s and the 1960s when the government split communities according to race under the Group Areas Act (No. 41 of 1950), as Brookes (2014) describes in her ethnographic study of tsotsitaal in Vosloorus, near Johannesburg. As a result of forced removals, generations of people who were born in the Johannesburg suburb of Sophiatown (before they were relocated to black townships, such as Soweto) spoke an Afrikaans-based tsotsitaal, whilst their offspring who were born in black townships spoke either an urban isiZulu-based tsotsitaal (in Soweto's historically Nguni sections, such as Zola and Dhlamini) or an urban Sesotho-based tsotsitaal (in Soweto's historically Sotho sections, such as Meadowlands and Dobsonville).

Following a better understanding of its linguistic structure and the reliance on speakers' vernacular languages for its grammatical base, tsotsitaal more recently has been characterised not as a language but as a register, or style, of speaking. Hurst and Mesthrie (2013) proposed the term 
TABLE 1: A summary of the respondents $(N=38)$.

\begin{tabular}{|c|c|c|c|c|c|c|c|c|}
\hline \multirow[t]{2}{*}{ Current location } & \multicolumn{4}{|c|}{ Age group } & \multicolumn{2}{|c|}{ Location of nurture } & \multicolumn{2}{|c|}{ First language (L1) } \\
\hline & $20-29$ & $30-39$ & $40-49$ & $50-60$ & North West & Gauteng & Setswana & Sesotho \\
\hline Rustenburg & 10 & 4 & 3 & 1 & 17 & 1 & 18 & 0 \\
\hline Klerksdorp & 4 & 2 & 0 & 3 & 9 & 0 & 8 & 1 \\
\hline Potchefstroom & 0 & 5 & 4 & 2 & 11 & 0 & 11 & 0 \\
\hline Total & 14 & 11 & 7 & 6 & 37 & 1 & 37 & 1 \\
\hline
\end{tabular}

'stylect' to refer to tsotsitaal and similar phenomena present in other urban centres (such as Sheng in Nairobi, etc.). The term 'stylect' is intended to incorporate non-linguistic aspects of the tsotsitaal style, which include gesture, clothing, music and lifestyle choices (Hurst \& Mesthrie 2013), and also to highlight the use of particular lexical items as part of a style performance in the construction of youth identity. As such, tsotsitaal is primarily characterised by re-lexicalisation and metaphor in the lexicon (Hurst 2016).

Although recent work has begun to compare geographical examples of tsotsitaal to identify, for example, a common core lexicon for tsotsitaal at a national level (such as Hurst's 2015 description of the commonalities and differences between tsotsitaals based on different languages in her comparison of a number of examples of tsotsitaal in the literature), and common linguistic structures and gestural features (Hurst \& Buthelezi 2014), more work is required in this area. In particular, whilst studies of tsotsitaal in a number of different base languages have been undertaken, no in-depth research on the Setswana-based tsotsitaal is currently available (apart from the study by Cook (2009), 'Street Setswana vs. School Setswana', which includes some tsotsitaal items, but does not specifically focus on this register). Furthermore, since Calteaux's (1996) work in Tembisa, no study has focused on differences in tsotsitaal varieties on a provincial scale. Such an analysis is able to tell us more about the spread of lexical items at a national level, and how terms become innovated at a local level.

Recent work by Hurst (2016) has examined the use of metaphor in tsotsitaal, and shown how discourse at a sentence or turn-level can lead to new coinages. However, the process of coinage of new lexical items in tsotsitaal has not yet been examined in detail. This article argues that new lexical innovations at a local level are often drawn from the local base language, in this case Setswana, because the local language offers the best opportunities for semantic shift and multiple meanings.

\section{Methodology}

In the tradition of a linguistic anthropology, there are various methods that could be used to gather data, including interviews and participant observation which were used in this study. According to Jackson (1995:17), participant observation is one of the methods that qualitative researchers use to understand how the respondents experience and explain their own world. Delamont (2004:218) adds that, 'Participant-observation means spending long periods watching people, coupled with talking to them about what they are doing, thinking and saying, designed to see how they understand their world'.

To gather data, the first author visited popular entertainment areas and mingled with the local people with a view to identify potential respondents, that is, people whose utterances were dominated by tsotsitaal.

With regard to what constitutes tsotsitaal, it was relatively easy for the first author to separate those who predominantly spoke colloquial Setswana from those who spoke tsotsitaal because he not only grew up speaking Setswana-based tsotsitaal but also studied Setswana academically and published literature in the language. In addition, he is a Setswana dialectologist (i.e. specialises in Setswana dialects), and has published work on Sepitori (or Pretoria Sotho) - a mixed language spoken by black residents of greater Pretoria (or Tshwane) as a lingua franca; this mixed language's substrate and superstrate are Setswana and Sesotho sa Leboa, respectively.

Setswana-based tsotsitaal-speaking male ${ }^{3}$ respondents aged 18-60 were interviewed at areas located just outside the North West's three biggest cities in terms of population and economy. The cities are Rustenburg, Klerksdorp and Potchefstroom. To be more specific, Rustenburg data were gathered at Tlhabane township and Geelhoutpark suburb (recording time: $61 \mathrm{~min}$ ); Klerksdorp data were gathered at Jouberton township (recording time: $25 \mathrm{~min}$ ); and Potchefstroom data were gathered at Ikageng township (recording time: $40 \mathrm{~min}$ ). Rustenburg is located about $140 \mathrm{~km}$ north-west of Johannesburg in the Bojanala Platinum District Municipality, whilst Klerksdorp and Potchefstroom are located about $170 \mathrm{~km}$ and $120 \mathrm{~km}$, respectively, south-west of Johannesburg in the Dr Kenneth Kaunda District Municipality.

\section{Data analysis}

This article will present data as follows:

- an example that shows the structural features of Setswanabased tsotsitaal

- 'new' tsotsitaal terms, and their semantics ('new' in this context refers to terms which may or may not be widely used or known to an average tsotsitaal speaker outside where they are used, but more significantly had not been captured in the known literature ${ }^{4}$ ).

3.Females who were approached refused to participate in the study because the believed that they either spoke colloquial or standard Setswana and not tsotsitaal.

4.In common with Hurst and Mesthrie (2013:7), the sources drawn on are 'not exhaustive, but cover a good range of regions in South Africa and a corresponding range of tsotsitaals utilising different matrix languages'. 


\section{Findings \\ Structural features}

The first example shows the Setswana base which forms the structure of tsotsitaal in the sampled cities. Tsotsitaal appears in italics and Setswana appears in normal font.

\section{Example 1}

Participant responded:

'Medi ga e le legaza, ga o ringe niks le yona; o vaya le yona ko wena.' [If a female has loose morals, you don't talk to her at all; you just take her to your place.] [Participant 1,30s, Klerksdorp]

Regarding the tsotsitaal terms, there are a number of terms in this example which are typical of tsotsitaal nationally. For example, medi (n) refers to a 'female' or 'girlfriend'. It is very popular in many versions of tsotsitaal across South Africa, and was also captured by Mulaudzi and Poulos (2001:6) from speakers of Tshivenda-based tsotsitaal. Similarly, ringe (v) is the negative form of ringa meaning 'to talk' or 'to chat'. It is very popular in many versions of tsotsitaal across South Africa, and was also captured by Ntshangase (1993:1) and seen in Hurst and Mesthrie's (2013:9) table of national tsotsitaal items. Finally, vaya (v) means 'to go'. Mulaudzi and Poulos (2001:5) submit that vaya is derived from an Afrikaans word waai, which means 'to blow', but can also mean 'to go' in contemporary Afrikaans. Hurst (2008:150) suggests that the origin of this term is disputed as some argue that it is instead derived from Portuguese 'to go' (vamos) and not Afrikaans. Despite disputes, speakers of tsotsitaal use it for 'to go'. The term is so popular that the City of Johannesburg's bus rapid transit (BRT) system is called $R e a^{5}$ vaya, which means 'we are going'.

On the other hand, in this sentence, as far as the authors are aware, legaza (n) is not found in previous literature on tsotsitaal, and refers to a 'female with loose morals'. The source or origin of this term could not be established from respondents and the known literature. It is also unclear whether it is derived from legosha or magosha, which is a widely used tsotsitaal term for a 'prostitute'; gosha (v) is a widely used tsotsitaal term, which means 'to sell one's body'. A more widely used term is letimela, which is derived from a Setswana verb timela or 'to be lost'. Mojela (2002:207) uses skebereshe (pronounced as skeberetšhe in the North West) from his work amongst Sesotho sa Leboa speakers, which is synonymous with legaza.

Regarding the structure of the Setswana which forms the base language or grammatical framework for this sentence, in common with other tsotsitaals around the country (Hurst \& Mesthrie 2013), the base reflects that of standard Setswana and may be influenced by the colloquial form (or dialect) of Setswana, rather than the standard form. For example, one could extend the sentence in example 1 and say '... ko wena gone yaanong' (Rustenburg dialect) or '... ko wena nou yaana' (Klerksdorp and Potchefstroom dialect), which means '... your place right now' (standard Setswana would be '... gona jaanong').

\section{New tsotsitaal terms}

\section{Example 2}

Participant responded:

'Ke tshwere m'rapper; e re a go kgzwêlê Motswako.' [I am with a rapper; let him perform Motswako for you.] [Participant 2, 30s, Rustenburg]

The lexical item $m^{\prime}$ rapper (n) in this example could be classified as a borrowing from English 'rap or hip hop singer', but it has been integrated into the grammatical frame of the Sotho language cluster. In the three Sotho languages, a human being is denoted by a noun class [mo-]; thus, a 'rapper' would be called 'mo-rapper'. The contraction $m^{\prime}$ rapper is part of being stylistic when speaking tsotsitaal.

The lexical item kgwêle (v) means 'to perform' or 'to sing'. It is derived from a Setswana verb $k g w a(y) a$, which means 'to spit'. In this context, it means 'to spit out' a popular mixed Setswana and/or English-based hip hop called Motswako. Here, the meaning of the Setswana lexical item provides the scope for the metaphorical semantic shift enabling the word to be applied to the context of music popular amongst township youth.

\section{Example 3}

Participant responded:

'A o mphase technician e e matšhobotla e le ya pakistan?' [Could you introduce me to that beautiful curvaceous domestic worker/ helper?] [Participant 3, 40s, Rustenburg]

In the example above, three of the terms appear to be drawn from English. The first term mphase (v), meaning 'introduce me to' or 'be instrumental in allowing me to have' or even 'pass me', is derived from an English verb 'to pass'. The second term technician (n) refers to a 'domestic worker' or 'helper' who is commonly a female. A 'technician' fixes a wide variety of items, and thus the meaning has been extended to a 'domestic worker' who 'fixes' or performs a wide variety of tasks in a household. The third term pakistan (n) refers to a 'curvaceous woman'. However, in this case, its meaning is actually derived from a Setswana verb paka, although originally from an English verb 'to pack' or even 'full of', in the sense that a curvaceous woman has more flesh around her pelvic bones. A 'curvaceous woman' is also called 'lepaka' or simply 'one packed with curves'. The word pakistan also cross-references the Asian country of Pakistan and signals a complex wordplay. This demonstrates multiple metaphorical meanings, a feature of many tsotsitaal terms that gain popular usage (Hurst 2016). In addition to these two terms, in Klerksdorp they use piere ('pear') and hour glass, both metaphorical borrowings from English slang. 
The final term in this example is matšhobotla (v), which means a 'beautiful woman'. The source or origin of this term could not be established from respondents and the known literature.

\section{Example 4}

Participant responded:

'Authi ya ka, ke gatile cable, ene ke verstanisitse majita.' [My brother, I am HIV positive, and I have informed my friends.] [Participant 4, 30s, Potchefstroom]

In this example, three of the lexical items are drawn from the national tsotsitaal lexicon. The term authi (n) derives from Afrikaans ou for 'man' and refers to a 'same/similar-aged male' or 'peer'. It is very popular in many versions of tsotsitaal across South Africa, and was also captured by Molamu (2003) who states that it refers to a 'lad' or 'young man'. In actual fact, authi is not limited to a 'young man' because males of the similar age (e.g. one aged 39 and another aged 41) can use the term to refer to one another. The commonly used tsotsitaal term for a 'lad' or 'young-er man' is a laaitie (also in common usage in South African English and in Afrikaans!) and it is also linked to age because a much older male (say, aged 49) can use the term to refer to one who is not old enough to be his peer (say, aged 41). Verstanisitse (v) past tense of verstanisa, means 'to make understand' and is adopted into tsotsitaal from an Afrikaans word verstaan, which means 'to understand'. Majita (n) refers to 'guys' or 'friends'. It is very popular in many versions of tsotsitaal across South Africa, and was captured by Sekere (2004) amongst speakers of Sesotho-based tsotsitaal. Its origins are disputed, but Hurst and Mesthrie (2013:9) suggest that it possibly comes from the English word 'jitterbug', which was the name of a style of dance in the 1930s to the 1940s in the United States. It should be noted, however, that slang etymologies tend to be complex and multiple, rarely linear, and that slang terms may hold different meanings for different speakers.

The expression gatile cable refers to being 'HIV positive'. In this expression, gatile is a Setswana verb (past tense of gata) for 'stepped over something', which may be dangerous. In this context, to gata cable refers to 'stepping over' a live electricity 'cable' or being infected with HIV. There is therefore a reliance on an understanding of both Setswana and English for the metaphorical meaning to be understood in this expression. Dowling (2004) wrote about expressions relating to HIV/AIDS and how taboo and avoidance are bypassed through metaphorical expressions to refer to this subject.

\section{Example 5}

Participant responded:

'Ke tsamaya le palone boy vandag; sepokothedi, tang ya mannete.' [I am accompanied by a rich boy today; someone who really has money.] [Participant 5, 30s, Potchefstroom]

Again in this example, the majority of the words are derived from English or Afrikaans. For example, palone boy or cheese boy (n) refers to a 'young male from a well-off family'. In some black communities, particularly those with a lower socio-economic status, bread and butter, peanut butter or jam were eaten for breakfast, but well-off families in addition to bread, butter, peanut butter or jam had other food items, such as polony and cheese. Over time, families which could afford polony and cheese were presumed to be well-off families, leading to coining tsotsitaal terms to refer to such families' children as polony boys and polony girls (or the more popular terms cheese boys and cheese girls). However, as some respondents from Rustenburg suggested, the term has also been extended to black children who went to private or multiracial schools and speak English in a former Model $C^{6}$ accent or an accent demonstrating having been educated at a suburban school, regardless of their families' socio-economic standing or status.

Vandag (n) means 'today' and is adopted into tsotsitaal from an Afrikaans word with the same meaning. This is also seen in Cape Town tsotsitaal (Hurst 2008). Tang (n) is an Afrikaans term for (a pair of) 'pliers' and in this context means a 'person with loads of cash'. Respondents stated that (a pair of) 'pliers' is an instrument that has the capacity to tightly hold many materials at a time; thus, someone who has lots of money is a tang, and would use a hand gesture to illustrate the sign for holding loads of cash. Upon probing in Klerksdorp and Potchefstroom, it emerged that a tang not only has loads of cash but also would be willing to spend it. Interestingly, tsotsitaal speakers at GaRankuwa (a Setswanadominant township in Gauteng province [henceforth Gauteng]) use the term for the diametrically opposite meaning; to them, a tang is a 'miser' as a (pair of) 'pliers' holds tight, a reference to someone who is very reluctant to part with money.

Sepokothedi (n) means a 'rich person'. In Sesotho, a 'pocket' is called pokotho (it is called pata or kgwatlha in Setswana). Also, the act of putting one's hands in their pockets (trousers) is called 'go pokothela', and it follows that colloquially, one who puts his or her hands in his or her pockets (trousers) is called 'sepokothedi'. Having said that, tsotsitaal speakers in Potchefstroom (and this holds true for Klerksdorp as well) have extended this act of putting hands in one's pockets to 'having money' because upon further probing they mentioned that sepokothedi is someone with 'deep pockets'. According to Census 2011, the following three languages have bigger L1 speakers at Dr Kenneth Kaunda District Municipality: Setswana (44.8\%), Afrikaans (18.4\%) and Sesotho (15.3\%). With Setswana and Sesotho being mutually intelligible, it is natural that where their speakers interact, some terms from the smaller language (Sesotho in this case) would cross over to the bigger one (Setswana in this case). Although this item has not been noted in the previous literature, its origin in Sesotho might mean that this term would be salient in multilingual townships in Gauteng, such as Soweto, where Sesotho is commonly spoken.

6.'Model C schools' were well-resourced pre-1994 schools in South Africa attended by white learners only. After 1994, these schools accepted learners of all race groups. The linguistic culture of these schools persists in the democratic South Africa, and The linguistic culture of these schools persists in the democratic South Africa, and
black learners who attend them may speak English and Afrikaans in accents that resemble those of white South Africans who speak these languages as L1s. 
TABLE 2: New tsotsitaal terms.

\begin{tabular}{|c|c|c|}
\hline Term & Meaning & Source language \\
\hline m'rapper & rapper, rap or hip hop singer & English \\
\hline kgwêlê & to perform, to sing & Setswana \\
\hline mphase & $\begin{array}{l}\text { to pass something to the } \\
\text { speaker }\end{array}$ & English \\
\hline technician & domestic worker, helper & English \\
\hline matšhobotla & beautiful woman & Unknown \\
\hline pakistan & curvaceous woman & Setswana \\
\hline lepaka & curvaceous woman & Setswana \\
\hline piere & curvaceous woman & English \\
\hline hour glass & curvaceous woman & English \\
\hline kobo & R10 note & Setswana \\
\hline tšhoko/choko & R20 note & English \\
\hline pinana & R50 note & English \\
\hline drata & R100 note & Afrikaans \\
\hline legaza & female with loose morals & Unknown \\
\hline letimela & female with loose morals & Setswana \\
\hline japa & tattoo & Unknown \\
\hline $\begin{array}{l}\text { palone boy or } \\
\text { cheese boy }\end{array}$ & $\begin{array}{l}\text { young male from a well-off } \\
\text { family }\end{array}$ & English \\
\hline sepokothedi & rich person & Sesotho \\
\hline tang & person with loads of cash & Afrikaans \\
\hline gata cable & being infected with HIV & $\begin{array}{l}\text { Setswana (gata) and } \\
\text { English (cable) }\end{array}$ \\
\hline sewašo/sewasho & liquor & English \\
\hline vuile water & liquor & Afrikaans \\
\hline magetla & $\begin{array}{l}750 \mathrm{ml} \text { of strong liquor (e.g. } \\
\text { whisky, brandy and gin) }\end{array}$ & Setswana \\
\hline popa & $\begin{array}{l}\text { to suddenly live comfortably or } \\
\text { achieve some success }\end{array}$ & English \\
\hline raba & to be arrested & English \\
\hline donti funda centre & uneducated person & English \\
\hline donti tšhawa/chawa & $\begin{array}{l}\text { person who has a disease } \\
\text { called 'gout' }\end{array}$ & $\begin{array}{l}\text { English (donti) and } \\
\text { Unknown (tšhawa/chawa) }\end{array}$ \\
\hline jangri† & foolish, naïve or gullible person & Unknown \\
\hline forogotlha & to drink, to take a sip & Setswana \\
\hline tsapi-tsapi & slowly or infrequently & Setswana \\
\hline sphandane & hustler & Unknown \\
\hline stoko & group of beautiful females & English \\
\hline
\end{tabular}

$\dagger$ Mojela (2002:205) offers the following terms: spaza, moggo, barri and kgashu, which are all synonymous with jangri and used across the three cities.

Table 2 summarises the new terms identified so far in the Setswana data, and their origin. Terms are classified as new because they have not been captured in the known literature. This list also includes terms which were not presented in the subsection above for reasons of space; their meanings have been provided.

Although Hurst and Mesthrie's (2013) data showed a predominance of English and Afrikaans-derived words in the national tsotsitaal lexicon, at a province level it is clear that many innovations are derived from the locally dominant language (in this case, Setswana).

\section{Similarities and differences in the three cities}

In terms of the spread of terms within the province, the use of the following terms appears to be predominantly used $^{7}$ in the areas mentioned, whilst the rest are used across the three cities.

7.It is possible that these terms may even be limited to the areas where they are predominantly used, but without evidence it would be difficult to suggest that with any certainty as some of them may already be used - even to a limited extent outside the North West province.
Rustenburg:

- technician

- matšhobotla

- donti funda centre

- donti tšhawa/chawa

- raba

Klerksdorp and Potchefstroom:

- legaza

- sepokothedi

- pinana

- japa

It is important to note that whilst the Rustenburg data were gathered at Tlhabane township and Geelhoutpark suburb, most of the tsotsitaal terms used at these areas were also used at other Rustenburg townships (e.g. Boitekong and Mogwase) and villages (e.g. Phokeng and Ledig). This was not only submitted by the respondents but also confirmed by the first author who was born, and grew up, in this area. Likewise, most of the tsotsitaal terms used in Klerksdorp (Jouberton township) and Potchefstroom (Ikageng township) were also used at other places within the Dr Kenneth Kaunda District Municipality, such as Stilfontein (Khuma township) and Hartbeesfontein (Tigane township), and this was submitted by the respondents.

This shows that the salience of these items has led to their takeup beyond the point of innovation, but still within the language community, which highlights an often metaphorical relationship between the semantic meaning and the shifted meaning of the term within tsotsitaal. At this stage, it is difficult to ascertain the extent to which these new tsotsitaal terms whose source language is Setswana have become 'conventionalised' and are being used by speakers whose base languages are not Sotho-Tswana languages. As such, more data need to be gathered, and it would be an interesting exercise to trace the geographical spread of terms, and their mode of distribution, for example, through popular music (Ditsele 2015).

Most of the tsotsitaal terms used in the three cities were known in each of the cities. However, there were terms which appeared to be used in Klerksdorp and Potchefstroom, but not known in Rustenburg (e.g. legaza). Similarly, there were terms which were used in Rustenburg, but not known in Klerksdorp and Potchefstroom (e.g. kobo for a R10 note). In Klerksdorp, only one respondent knew what kobo meant, and he indicated that he went to high school in Rustenburg and only used the term when he visits this city. So despite these cities sharing a common language, there are even more local innovations that do not make it into the tsotsitaal of the wider language community.

\section{Conclusion}

This study shows that the tsotsitaal spoken in the North West uses Setswana as its ML, and this is consistent with Brook's findings, who submits the following:

The individuals who responded to my search for tsotsitaal speakershad mother tongues including isiZulu, isiXhosa, Sesotho, 
Setswana and English. What I discovered was that these native speakers all spoke a different version of tsotsitaal that appeared to depend on the speaker's native language, while incorporating lexicon from Afrikaans as well as isiZulu and isiXhosa, and, to lesser degrees, Sesotho, Setswana, Sepedi, Tshivenda and Xitsonga. (2010:2)

Brook's (2010) respondents incorporated lexicon from languages which had vitality in areas where data were gathered. Consistent with this finding was that, in Klerksdorp and Potchefstroom, pockets of Sesotho lexicon made it into the Setswana dialects (and by default the tsotsitaal versions), a phenomenon which was not picked up in Rustenburg's Setswana dialect because of the city's much lower population of speakers of other Bantu languages.

Respondents used many widely used terms such as medi, ringa, authi, majita, vaya, tiger, klipper and spana. This confirms the findings of previous studies which noted that tsotsitaal is a dynamic language, and its terms travel from its epicentre to other regions; yet, although speakers used many terms which, according to previous studies, were coined in Gauteng (particularly Johannesburg), they also used new or local coinages. These coinages were often developed from Setswana - the local language - using sematic shift and metaphor, and some exhibited multiple meanings as in the case of pakistan. Items with multiple meanings, and therefore wider salience, seem more likely to be adopted outside the language community and thus make it into the 'national' tsotsitaal lexicon, although terms may also be popularised through routes such as popular music and television. There is some suggestion that words derived from English and Afrikaans are more likely to make it into the national lexicon as many South Africans speak these languages as an additional language. Therefore, their (metaphorical) meaning is accessible to a wider proportion of South Africans than words developed from languages that do not have a national footprint. However, these findings are tentative, and more research needs to be conducted on the phenomenon.

The authors found that each city believed that its tsotsitaal version was the most sophisticated as one respondent from Rustenburg submitted, 'Rusty e thôpa di-kasi tse baie ka language ya se-cleva' (Rustenburg outperforms many townships when it comes to township lingos.). More interestingly, respondents suggested that the tsotsitaal versions spoken in the other cities in the North West were heavily influenced by standard Setswana, and that made such versions less sophisticated. In other words, they believed that the strong influence of standard Setswana depicts less sophistication. One respondent in Klerksdorp remarked, 'If you want pure Setswana, you should go to Rustenburg, Mafikeng or Potchefstroom; here we speak mixed languages.' Be that as it may, the authors observed that the Setswana dialect spoken in each city was the ML for the tsotsitaal versions spoken; thus, the suggestion about the strong influence of standard Setswana elsewhere was just a perception. The data also confirmed the idea that the most urban or colloquial form of the local language is used as the base language of tsotsitaals.

\section{Recommendations for more research}

Ndlovu (2015) illustrates that tsotsitaal has crossed the South African border into Zimbabwe where it has influenced the urban lingo (called S'ncamtho) spoken in Bulawayo, a city in which Northern isiNdebele is the most dominant language. Northern isiNdebele is a Nguni language and closely related to isiZulu. S'ncamtho (called iscamtho in South Africa) uses Northern isiNdebele as its ML.

Setswana is a cross-border language of about 5.3 million L1 speakers in Southern Africa and has official status in South Africa, Botswana and Zimbabwe. It also has L1 speakers in Namibia, albeit small in number. Anecdotal evidence suggests that tsotsitaal has also crossed the South African border into Botswana, and naturally the ML of this country's tsotsitaal version is Setswana.

As a follow-up to this study, in addition to further data from the North West, research needs to be conducted in Botswana with a view to undertaking a comparative analysis between the Setswana-based tsotsitaal spoken in South Africa and that spoken in Botswana, amongst others, to establish the extent to which tsotsitaal lexicon travels across the border.

\section{Acknowledgements}

We wish to express our sincere thanks to the National Research Foundation (NRF) (grant number 90273) for assisting us with funding to conduct this study. We would also like to thank our respondents in Rustenburg, Klerksdorp and Potchefstroom for allowing us to record and speak to them about their versions of Setswana-based tsotsitaal.

\section{Competing interests}

The authors declare that they do not have any financial or personal relationships which may have inappropriately influenced them in writing this article.

\section{Authors' contributions}

T.D. conceptualised the article, gathered data and wrote the first draft. Both T.D. and E.H. contributed equally to the final version of the article.

\section{References}

Brook, K., 2010, 'Interactions of South African languages: Case study of tsotsitaal', paper read at the Global Wordnet Conference, Mumbai, India, 31 Jan-04 Feb, viewed 03 January 2016, from http://www.globalwordnet-iitb2010.in/ proceedings.php

Brookes, H., 2014, 'Urban youth languages in South Africa: A case study of tsotsitaal in a South African township', Anthropological Linguistics 56(3-4), 356-388. http:// dx.doi.org/10.1353/anl.2014.0018

Brookes, H. \& Lekgoro, T., 2014, 'A social history of urban male youth varieties in Stirtonville and Vosloorus, South Africa', Southern African Linguistics and Applied Language Studies 32(2), 149-159. http://dx.doi.org/10.2989/16073614.2014.992642

Calteaux, K., 1996, Standard and non-standard African language varieties in the urban areas of South Africa: Main report for the Stanon Research Programme, Human Sciences Research Council, Pretoria.

Census, 2011, viewed 3 January 2016, from http://www.statssa.gov.za/Census2011/ Products/Census_2011_Census_in_brief.pdf 
Cook, S.E., 2009, 'Street Setswana vs. school Setswana: Language policies and the forging of identities in South African classrooms', in J.A. Kleifgen \& G.C. Bond (eds.), The languages of Africa and the Diaspora: Educating for language (eds.), The languages of Africa and the Diaspora:
awareness, pp. 96-116, Multilingual Matters, Bristol.

Delamont, S., 2004, 'Ethnography and participant observation', in C. Seale, G. Gobo, J.F. Gubrium \& D. Silverman (eds.), Qualitative research practice, pp. 217-229, Sage, London.

Ditsele, T., 2015, 'Use of tsotsitaal in South African music', paper read at the 2nd African Urban Youth Language Conference, December 11-13, Nairobi, Kenya.

Dowling, T., 2004, 'UQedisizwe the finisher of the nation: Naming and talking about HIV/AIDS in African languages', Unpublished paper.

Halliday, M.A.K., 1975, 'Anti-languages', American Anthropologist 78(3), 570-584. $\mathrm{http}: / / \mathrm{dx}$.doi.org/10.1525/aa.1976.78.3.02a00050

Hurst, E., 2008, 'Style, structure and function in Cape Town tsotsitaal', Doctoral thesis, University of Cape Town.

Hurst, E., 2009, 'Tsotsitaal, global culture and local style: Identity and recontextualisation in twenty-first century South African townships', Social Dynamics 35(2), 244-257. http://dx.doi.org/10.1080/02533950903076196

Hurst, E., 2015, 'Overview of the tsotsitaals of South Africa: Their different base language and common core lexical items', in N. Nassenstein \& A. Hollington (eds.), Youth language practices in Africa and beyond, pp. 169-184, De Gruyter Mouton, Berlin.

Hurst, E., 2016, 'Metaphor in South African tsotsitaal', Sociolinguistic Studies 10(1-2), 153-175. http://dx.doi.org/10.1558/sols.v10i1-2.27922

Hurst, E. \& Buthelezi, M., 2014, 'A visual and linguistic comparison of features of Durban and Cape Town tsotsitaal', Southern African Linguistics and Applied Language Studies 32(2), 185-197. http://dx.doi.org/10.2989/16073614.2014.992645

Hurst, E. \& Mesthrie, R., 2013, “"When you hang out with the guys they keep you in style": The case for considering style in descriptions of South African tsotsitaals', Language Matters: Studies in the Languages of Africa 44(1), 3-20. http://dx.doi.org/10.1080/10228195.2012.744082

Jackson, W., 1995, Methods: Doing social research, Prentice Hall, Scarborough, ON.

Makalela, L., 2013, 'Translanguaging in kasi-taal: Rethinking old language boundaries for new language planning', Stellenbosch Papers in Linguistics Plus 42, 111-125. $\mathrm{http}: / / \mathrm{dx}$.doi.org/10.5842/42-0-164
Maribe, T. \& Brookes, H., 2014, 'Male youth talk in the construction of black lesbian identities', Southern African Linguistics \& Applied Language Studies 32(3) identities', Southern African Linguistics \& Applied Languag

Mesthrie, R., 1989, 'The origins of Fanagalo', Journal of Pidgin \& Creole Languages 4(2), 211-240. http://dx.doi.org/10.1075/jpcl.4.2.04mes

Mesthrie, R., 2008, "I've been speaking Tsotsitaal all my life without knowing it' Towards a unified account of tsotsitaals in South Africa', in M. Meyerhoff \& N. Nagy (eds.), Social lives in language, pp. 95-109, Benjamins, New York City, NY.

Mesthrie, R. \& Hurst, E., 2013, 'Slang registers, code-switching and restructured urban varieties in South Africa: An analytic overview of tsotsitaals with special reference to the Cape Town variety', Journal of Pidgin \& Creole Languages 28(1), 103-130. http://dx.doi.org/10.1075/jpcl.28.1.04mes

Mojela, V.M., 2002, 'The cause of urban slang and its effect on the development of Northern Sotho lexicon', Lexikos 12, 201-210.

Molamu, L., 2003, Tsotsi-Taal: A dictionary of the language of Sophiatown, University of South Africa, Pretoria.

Mulaudzi, P.A. \& Poulus, G., 2001, 'The 'Tsotsi' language variety of Venda', South African Journal of African Languages 21(1), 1-8.

Ndlovu, S., 2015, 'Evolution of S'ncamtho greetings in Bulawayo', paper read at the 2nd African Urban Youth Language Conference, December 11-13, Nairobi, Kenya.

Nkosi, D., 2008, 'Language variation and change in a Soshanguve high school', Master's dissertation, University of South Africa, Pretoria.

Ntshangase, D., 1993, 'The social history of Iscamtho', Master's dissertation, University of the Witwatersrand, Johannesburg.

Rudwick, S., 2005, 'Township language dynamics: isiZulu and isiTsotsi in Umlazi', Southern African Linguistics and Applied Language Studies 23(3), 305-317. http:// Southern African Linguistics and Applied Lomg
dx.doi.org/10.2989/16073610509486392

Sekere, N., 2004, 'Sociolinguistic variation in spoken and written Sesotho: A case study of speech varieties in Qwaqwa', Master's dissertation, University of South Africa, Pretoria.

Slabbert, S. \& Myers-Scotton, C., 1997, 'The structure of tsotsitaal and Iscamtho: Codeswitching and in-group identity in South African townships', Linguistics 35, 317-342. http://dx.doi.org/10.1515/ling.1997.35.2.317

South Africa, 1950, Group Areas Act, No. 41 of 1950. 